\title{
雜錄
}

\section{臺灣産おとぎりさう屬植物 (摘要)}

木 村 陽 二 郎

臺灣ニ於ケルおとぎりさう科植物 (Hypericaceae) 八多クノ分類學者ノ如クおと ぎりさう屬习大キク取扱フトおとぎりさう屬 Hypericum トをいわんきんしばい屬 Takasagoya トニ分レ，おとぎりさう屬ヨおとぎりさう節 (Euhypericum)，ともえ さう節 (Roscyna)，をんしばレ節 (Norysca)，ひめおとぎり節 (Brathys) ト二分ツ事. ガ出來ル。即チ

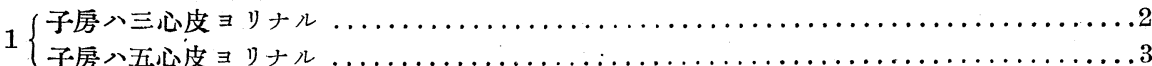

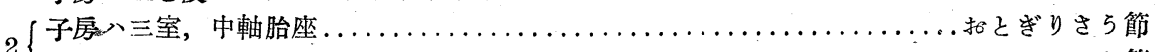

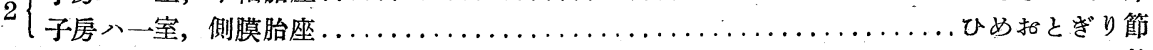

${ }_{3}\{$ 花後花瓣及ビ雄菻群八脫落スル，小灌木 $\ldots \ldots \ldots \ldots \ldots \ldots \ldots \ldots \ldots \ldots$.

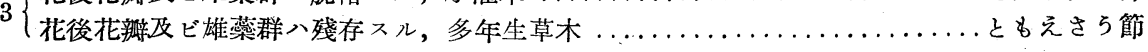

きんしばい節ニ屬スルきんしばい（Hypericum patulum THUNB.)，びやうやなぎ (H. salicifolium SIEB. et ZUCC.) 八栽培種見ナサレル故コレヨ除ケバ臺灣二八お とざりさう屬 (Hypericum) 11 種习産スル。郎チ次ノ如シ

(1) H. pseudopetiolatum KELLER さはおとぎり var. taihezanense (SUZUKI) Y.KIMURA たいわんあぜおとざり, 臺灣畔弟切

(2) H. erectum THUNBERG おとぎりさう var. angustifolium X. KIMURA 法そばおとぎり, 細葉弟切

(3) H. Nagasawai HaYata にひたかおとぎり var. typicum Y. KIMURA にひたかおとざり, 新高弟切 var. nigrum Y. KIMURA にひたかくろおとぎり，新高黑弟切 (新變種)

(4) H.randaiense HAYATA らんだいおとぎり，戀大弟切

(5) H.taiwanianum Y. KIMURA つぎたかおとぎり，次高弟切 (新種)

(6) H. nokoense $\mathrm{OHWI}$ 乙めばおとぎり, 米葉弟切

( 7 ) H. Hayatae Y.KIMURA あつばおとざり，厚葉弟切（新種）

(8) H. Suzukianum Y. KIMURA たいわんやまおとぎり，臺灣山弟切 (新種)

(9) H. Sampsoni HANCE つをぬを技ときり，突拔弟切

(10) H. Ascyron L. と夕总さう var. genuinum Maximowicz とも总さう, 巴草

(11) H. japonicum THUNBerG ひめおとぎり var. typicum HocHREUTINER ひめおときり, 姬弟切 var. lanceolatum Y. KIMURA ほそばひめおとぎり，細葉姬弟切 (新變種) 
(1) ヨリ (9) マデノ種八おとざりさう節 (Euhypericum) =屬シソノウチ (9)つき ぬきおとぎり八子房壁及ビ果皮ノ腺體八隋圓球ヨナシ花辫二八邊緣二一列ノ細胞 リナル毛アル故, 他卜異りつきぬきまさきり亞節 (Subsect. Drosocarpium) =屬シ他 ノおとぎりさう亞節 (Subsect. Homotaenium) 卜異ル 郎于後者八子房壁及ビ果皮ノ 腺體ハ線形ヨナシ花瓣ニ八毛ガナイ。後者二屬スル種〉檢索表ヨ次ニ示ス。

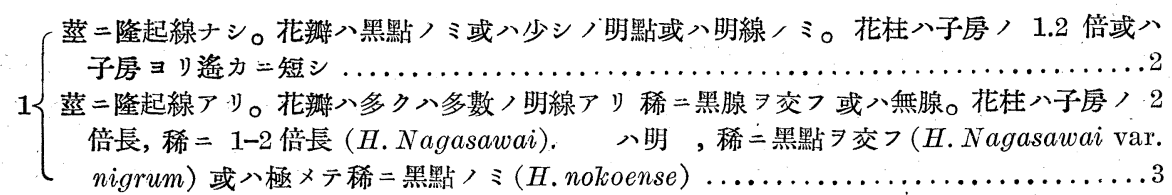
$2\left\{\begin{array}{r}\text { 花桂八子房ヨリ短シ。花瓣八透明線或八透明點或八無腺。葉二八稍々葉柄アリ } \\ \text { H. pseudopetiolatum var. taihezanense }\end{array}\right.$ 花柱八子房，1.2 倍長。花瓣八黑點アリ,葉バ稍々菛ヨ抱ク H. erectum var. angustifolium (花桂八子房ヨリ少シク (凡ソ $1.2-1.3$ 倍) 長イ。莖ハ凡ソ $5-17 \mathrm{~cm}$ 時 $=23 \mathrm{~cm}=$ 達ス。葉八 披針狀長棈圆形。蓦片ハ少シク尖ル文八鈍頭。花瓣ハ透明線又心稀二黑線アリ

3\{

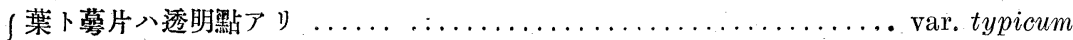

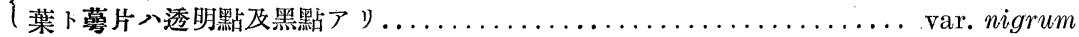

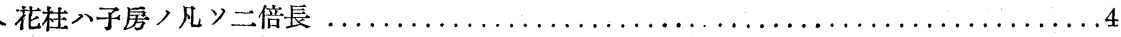

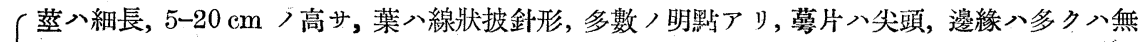

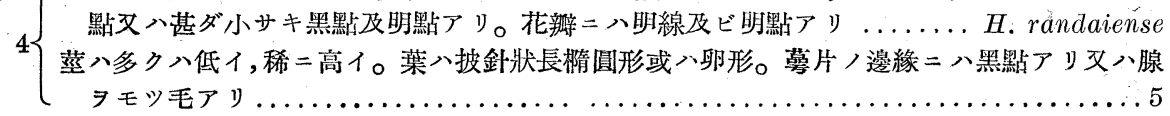

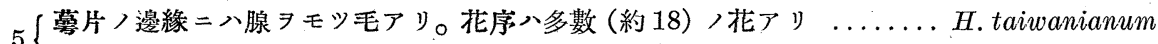

$5\{$ 萝片八全邊，邊緗一八黑點アリ。花序 ハ小數 (約 $1-3$, 稀=6) 花 $\ldots \ldots \ldots \ldots \ldots \ldots \ldots$ 小形ノ植物，高サ 5-10 cm，葉八卵形文八楕圆狀卵形，小，凡ソ 4-6 mm/長サ，黑點アり。

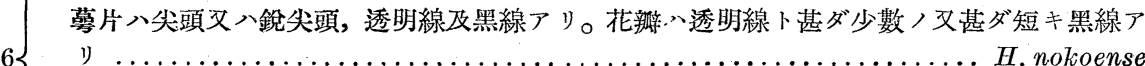

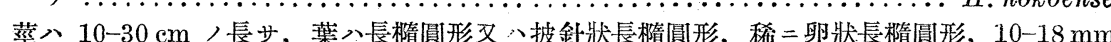

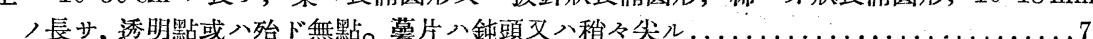

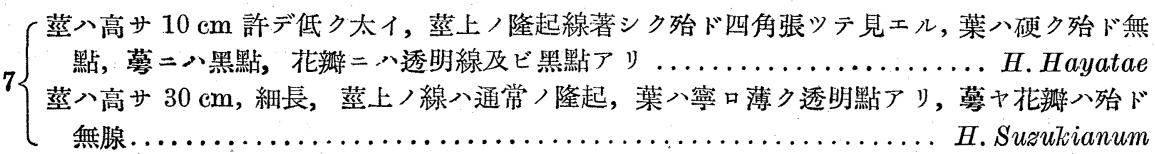

上記ノ检索表ニモ見ラレル如クたんわんあぜおとぎり及ビほそばおとぎり 除ケ バ他ノ 6 種八皆互ヒニ似テーツノ群ヨナシソノ特徵ハ检索表ノ 1 カラ 3 移ル處二 示サレテキル。コノ6 種八總テ臺灣特有ノ植物デアリ皆高山ニ産スル。夜ときりりさ う屬 Hypericum 特二末とぎりさう節 Sect. Euhypericum 八南方二行ク二從七種類 八著シク減少スルノデ海南島ニハひめおとぎりノミアリ。印度支那ニハひめおとぎ りトつをぬき括とさりトコノ節ニ屬スルH.napaulense CHoIs. ノミアリ。フイリッ ピンニハひめおとぎりノ他ニバシー海峽习隔テ、臺灣二對立スル北ルゾンノ高地二 固有種 H. Loheri MerR. (700-1600 m),H. pulogense MerR. (2800 m) 及ビ H. Lackeyi ELMER ラ座スルノミデアル。臺灣二比較的多數種ヨ產スルノ八 $3000 \mathrm{~m}$ 以上ノ高峯 
50 有餘ヨ有スル程高山ガ多イタメト思ハレル。

コノ臺灣ノおとざりさうノ代表的ナモノ八故早田博士ノ記載サレタにひたかおと ぎりトらんだい括とぎりデ前者八大霸尖山，鹿場大山，次高山，大平山，南湖大山， 等萊主山, 能高山, 新高山トイフヤウ二主トシテ北二位置スル次高山塊及ビ北部ノ臺

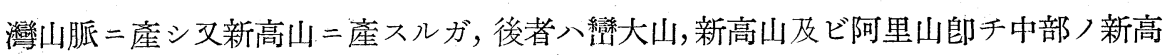
山脈三產スル。乙めばおとざり八能高越ニテ大井氏自ラ探集サレ新種トサレタモノ， つぎたか括とぎり八次高山二テ大橋捨三郎氏ノ採集サレタモノデアリあつばおとぎ り八森丑之助氏ガ白狗大山ニテ採集サレタモノデアリ, 臺灣植物ノ研究フサレタ故 早田敎授习記念シテ H. Hayatae ト名付ケタ。たいわんやまおとざり八臺中州ノ椚 ケ岡 $(2300 \mathrm{~m})$ 二テ鈴木重良氏ノ採集サレタモノデ臺北帝大ノ腊葉室ノ充實ニカヨ 入レテ廣ク探集サレタ故鈴木重良氏 (1894-1937) ヨ記念シテ H. Suzukianum ト名 付ヶ夕。此等ノ種ノ標本ガ更二增七バ種ノ間ノ關係モ更二明瞭トナルト思ハレル。

故早田敎授ガ鹿場大山デ記載サレタたんさんおとざり (H. taisanense HAYATA) > おとぎりさうノ變種在そばおとざり(H. erectum THUNB. var. angustifolium) =他 ナラズ，おとぎりさう(H. erectum THUNB.) 八琉球マデ來テ年タガ從來臺灣二八見 ラレナカツタ。ヌコノ種八臺灣デハ其後採集シタ人ヨ聞カナイモノデアツテ分布上 多少奇異, 感ジガスル，產地八鹿場大山トイツテモ低イ場所二相違ナイ。たいわん さは打とぎり (H. taihezanense S. SUZUKI) トシテ發表サレタモノ八筆者方植物研究 雜誌第十五卷五・六號ニ示シタ如クさはおとぎり（H. pseudopetiolatum KELLER）， 變種デアツテ臺北州及ビ新竹州ノ北部ノ山地卜阿里山附近二產スル。

つきぬきおをぎ文支那南部, 佛領印度支那, 印度 (カーシア地方), 臺灣 (臺北州, 新竹州), 九州西部, 四國南部二產スルモノデアル。

とも急さう八島田彌市氏二依レバ新竹市附近二限ラレテ產ス, コノ附近八支那福 建省ノ植物卜關係ガ深イラシイ。北海道, 本州, 四國, 九州, 臺灣, 朝鮮, 滿州, シベ 吊, 支那二產スル。

ひめおとぎりハ本州南部, 九州, 四國, 琉球, 臺灣, 朝鮮, 支那, 佛領印度支那, 馬 來, フイリッピン, ジヤバ, 濠州, タスマニア，二ニージーランドニ產スル廣イ分布 ヨモツタモノデアル。此度島田彌市氏ガ探集サレタモノ二全株葉八披針狀ノモノガ アツタ。產地入新竹州ノ仙脚厝デ海岸ノ附近デコレヨ var. lanceolatum ト名付ヶタ。 ひめおとぎりハとけおとぎり卜異り托葉ガ披針形ナノデ判然トシテキルガ此度，葉 モ披針形ノモノガアラハレタ事入興味アル事デアル。

ゴ, 研究ニアタリ終始御指導御䩒達下サツタ中井猛之進敎授及ビ臺北帝國大學理 農學部所藏, 弟切草科植物ノ標本 7 御貸與下サツ夕日比野信一敉授, 山本由松博士

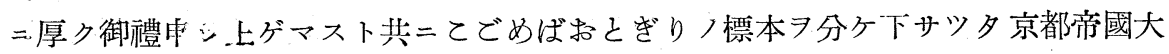
學入大井次三郎博治。臺灣入地名其他ニツキ御知ラセ下サツ夕臺北帝國大學鈴木時

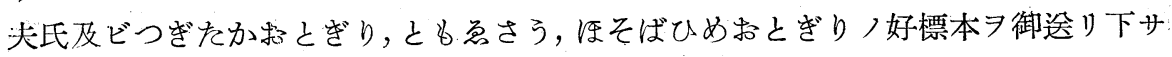
ツ夕島田彌市氏 $=$ 感謝致ス次第デス。 